\title{
Acne on Pigmented Skin: Epidemiological, Clinical and Therapeutic Features in Dermatology in Benin
}

\author{
B. Dégboé ${ }^{1 *}$, C. Koudoukpo², N. Agbéssi², N. Elégbédé-Adégbitè ${ }^{1}$, F. Akpadjan1, H. Adégbidi ${ }^{1}$, \\ F. Atadokpèdé 1
}

\begin{abstract}
${ }^{1}$ Service of Dermatology and Venerology, National Teaching Hospital HKM of Cotonou, Faculty of Health Sciences, University of Abomey-Calavi, Abomey-Calavi, Benin

${ }^{2}$ Service of Dermatology and Venerology, Department Teaching Hospital of Borgou-Alibori, Faculty of Medicine, University of Parakou, Parakou, Benin

Email: *kebdegboe@yahoo.fr
\end{abstract}

How to cite this paper: Dégboé, B., Koudoukpo, C., Agbéssi, N., Elégbédé-Adégbitè, N., Akpadjan, F., Adégbidi, H. and Atadokpèdé, F. (2019) Acne on Pigmented Skin: Epidemiological, Clinical and Therapeutic Features in Dermatology in Benin. Journal of Cosmetics, Dermatological Sciences and Applications, 9, 305-312.

https://doi.org/10.4236/jcdsa.2019.94027

Received: September 17, 2019

Accepted: November 26, 2019

Published: November 29, 2019

Copyright $\odot 2019$ by author(s) and Scientific Research Publishing Inc. This work is licensed under the Creative Commons Attribution International License (CC BY 4.0).

http://creativecommons.org/licenses/by/4.0/

\begin{abstract}
Purpose: The aim of this work was to describe the epidemiological, clinical and therapeutic features of pigmented skin acne in Benin. Methods: This was a prospective, cross-sectional and analytical study conducted in the dermatology departments of the Borgou-Alibori Departmental Teaching Hospital and the National Teaching Hospital Hubert Koutoukou Maga from January 2017 to December 2018, which has included black-skinned patients who were diagnosed with acne and gave their free and informed consent. The ECLA score was used for clinical evaluation of the severity of the acne. Results: We collected 129 patients including 35 men and 94 women. The median age of the patient was 24.6 years \pm 8.5 years. The median age of onset was 17.9 years \pm 7.6 years. The main triggering of worsening factors was inadequate self-medication (53.5\%), excoriation (48.1\%), certain foods (34.9\%) and lightening cosmetic (32.5\%). Most patients had inflammatory (51.9\%) or comedonal (31.8\%) acne associated with post-inflammatory hyperpigmentations (70.5\%) and excoriated lesions (31\%). In the majority of cases, acne was moderate in women $(52.1 \%)$ and severe in men $(62.8 \%)$ with $\mathrm{p}=9 \times 10^{-3}$. The lesions were electively seated in the face $(95.3 \%)$, mainly on the forehead and cheeks. Active cosmetics (76.7\%), retinoids (58.9\%), oral antibiotics (55.8\%), and benzoyl peroxide (48.9\%) were the most commonly used therapeutic classes. Conclusion: The majority of young and adult women consulted for predominant inflammatory acne on the forehead and cheeks, moderate in woman and severe in men in Benin. The therapeutic arsenal consisted mainly of active cosmetics, retinoids, antibiotics and benzoyl peroxide.
\end{abstract}




\section{Keywords}

Inflammatory Acne, Adult Acne, Active Cosmetic, Pigmented Skin, Benin

\section{Introduction}

Acne is a chronic inflammatory dermatosis of the pilo-sebaceous follicle evolving by attacks and particularly affecting the seborrheic zones [1] [2] [3] [4].

It is traditionally recognized as physiological dermatosis of adolescents, affecting more than $80 \%$ of them. It is more and more common in adults [4] [5] [6] [7].

Its pathogenesis involved both internal and external factors. Although its physiopathology remains the same, its clinical presentation varies according to skin phototypes [8] [9] [10] [11] [12]. Inflammatory lesions and post-inflammatory hyperpigmented scars appear to be common on pigmented skin [9] [10] [11] [13]. This difference in clinical presentation should lead to a diversification of the therapeutic attitude. Cosmetic containing a skin bleaching agent combined with a photoprotective agent for application in the morning, must be systematically prescribed. But, it is the same treatment used in acne in white skin which is usually prescribed for acne in pigmented skin [4] [9] [10] [13].

In view of the epidemiological evolution and the different clinical aspects, we proposed to document of the epidemiological, clinical and therapeutic features of acne in our context.

\section{Material and Methods}

We carried out a prospective, transversal and analytical study in the dermatology departments of the Borgou-Alibori Departmental Teaching Hospital in Parakou and the National Teaching Hospital Hubert Koutoukou Maga (CNHU-HKM) in Cotonou. These two hospitals are the first two Teaching hospitals in Benin, the first being in the north and the second in the south of Benin. From January 2017 to December 2018, we included patients who had a clinical diagnosis of acne and gave their free and informed consents to participate in the survey. Epidemiological, clinical and therapeutic data were collected on a survey sheet. The Clinical Assessment of Acne (ECLA) score was use to assess the severity of the disease. These data were entered anonymously and analyzed with EPI INFO7 and SPSS16.

\section{Results}

We include 129 subjects, 35 men (27.1\%) and 94 women (72.9\%). The median age of the patient was 24.6 years \pm 8.5 years with extremes of 11 years and 56 years. Young people aged 18 - 24 years $(48.8 \%)$ and adults aged $25-45$ years (36.4\%) were most represented. Adults ( $\geq 25$ years) made up $38.7 \%$ of population, or 50 patients, while pubescent and adolescents (10 - 17 years) represented 


\section{$12.4 \%$, or 16 patients (Figure 1 ).}

The median age of onset was 17.9 years \pm 7.6 years. The median consultation time was 5.1 years \pm 7.1 years.

Triggering or aggravating factors were inadequate self-medication (53.5\%), excoriation $(48.1 \%)$, certain foods $(34.9 \%)$ and lightening cosmetics $(32.5 \%)$ or comedogenic cosmetics (9.3\%) and mechanical factors (4.6\%).

Hyperseborrhea was present in all patients most of moderate (45.7\%) to mild (7.2\%). The predominant elementary lesions (Table 1 ) were the papules $(79.1 \%)$, the microcysts $(76 \%)$, the comedons $(71.3 \%)$, and the post-inflammatory hyperpigmentations (70.5\%).

The lesions were electively seated in the face (95.3\%), mainly on the forehead (92.2\%), the cheeks (86.8\%), the temples (57.4\%), and the chin (54.3\%). Out the face, there was thoracic involvement (33.3\%), shoulders (12.4\%), arms $(8.5 \%)$, and the lower back (7\%).

Most patients had inflammatory (51.9\%) or comedonal $(31.8 \%)$ acne. Nodulo-cystic acne was found in $15.5 \%$ of patients (Table 1 ).

The average ECLA score was $10 \pm 5$ (Figure 2). Moderate acne (ECLA: 6 - 12) was common (43.5\%) followed by severe acne (ECLA > 12; 34.7\%) and mild acne (ECLA $<6 ; 21.8 \%)$. Acne was mild in $17.1 \%(6 / 35)$ of men versus $22.3 \%$ (21/94) of women, moderate in 20\% (7/35) of men versus $52.1 \%$ (49/94) of women and severe in $62.9 \%(22 / 35)$ of men versus $25.5 \%(24 / 94)$ of women; $\mathrm{p}=$ $9 \times 10^{-3}$.

The treatment initiated was dominated by topical treatment (94.6\%) versus systemic treatment (59.7\%). The therapeutic arsenal (Table 2) consisted mainly of active cosmetic (99; 76.7\%), oral antibiotic $(72 ; 55.8 \%)$ and retinoids (76; $58.9 \%)$. The photo-protector has been prescribed in a single patient.

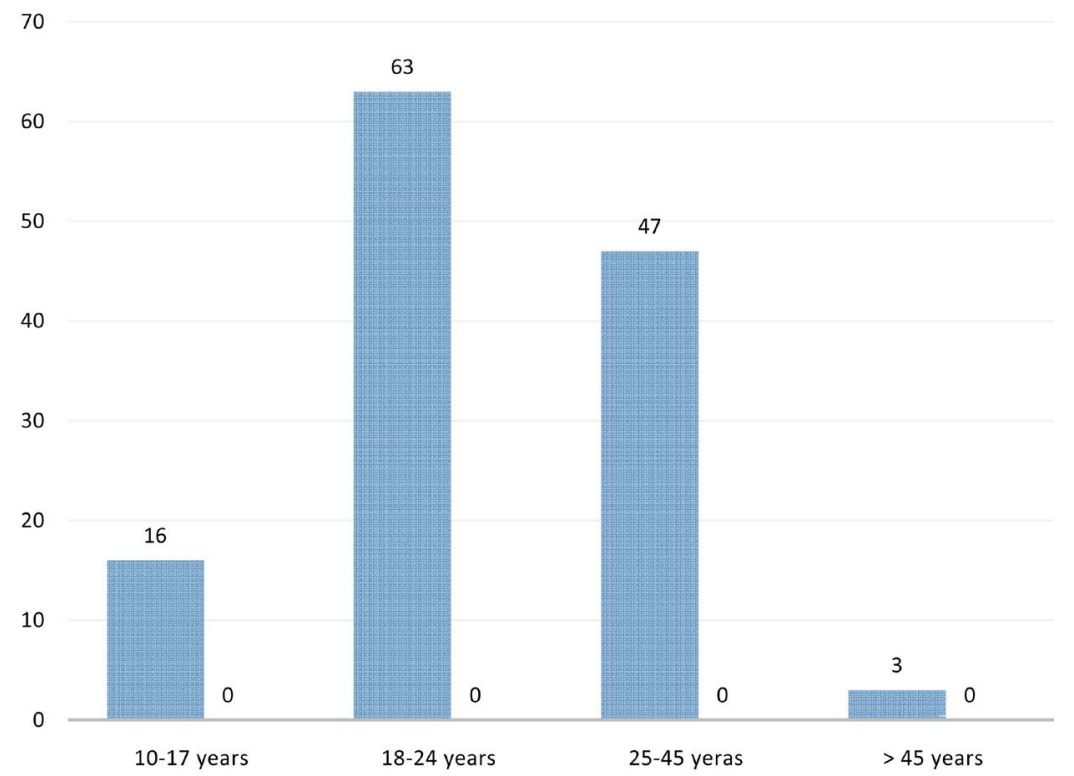

Figure 1. Age distribution of 129 acneic patients seen in Departments of Dermatology in CNHU-HKM Cotonou and CHUD-B/A Parakou at January 2017 to December 2018. 
Table 1. Clinical aspects of acne in 129 patients seen in Departments of Dermatology in CNHU-HKM Cotonou and CHUD-B/A Parakou at January 2017 to December 2018.

\begin{tabular}{|c|c|c|}
\hline Elementories lesions & Number & Frequency (\%) \\
\hline Hyperseborrhea & 129 & 100 \\
\hline Comedons & 92 & 71.3 \\
\hline Microcystic lesions & 98 & 76 \\
\hline Papule & 102 & 79.1 \\
\hline Pustular lesions & 49 & 38 \\
\hline Post-inflammatories hyperpigmentations & 91 & 70.5 \\
\hline Snow-peak scars & 14 & 10.9 \\
\hline Nodules & 20 & 15.5 \\
\hline Edema & 2 & 1.6 \\
\hline Excoriated lesions & 40 & 31 \\
\hline \multicolumn{3}{|l|}{ Clinical forms } \\
\hline Comedonal acne & 41 & 31.8 \\
\hline Inflammatory acne & 67 & 51.9 \\
\hline Pigmented acne & 5 & 3.9 \\
\hline Conglobata acne & 6 & 4.7 \\
\hline Excoriated acne & 6 & 4.7 \\
\hline Cicatricial acne & 4 & 3.1 \\
\hline Acneic tetrad & 1 & 0.8 \\
\hline
\end{tabular}

Table 2. Treatments used of acne in 129 patients seen in Departments of Dermatology in CNHU-HKM Cotonou and CHUD-B/A Parakou at January 2017 to December 2018.

\begin{tabular}{ccc}
\hline Type of treatment & Number & Frequency (\%) \\
\cline { 2 - 3 } Topical treatment & $\mathrm{N}=129$ & 94.6 \\
Active cosmetics & $\mathbf{1 2 2}$ & $\mathbf{7 6 . 7}$ \\
Retinoïds & $\mathbf{9 9}$ & $\mathbf{5 8 . 9}$ \\
Benzoyl peroxide & 76 & $\mathbf{4 8 . 9}$ \\
Antibiotics & 63 & 32.6 \\
Photoprotector & 42 & 0.78 \\
Azelaïc acid & 1 & 0.78 \\
Systemic treatment & 77 & 59.7 \\
Antibiotics & 72 & 55.8 \\
Zinc gluconate & 2 & 1.6 \\
Isotretinoin & 3 & 2.3 \\
\hline
\end{tabular}




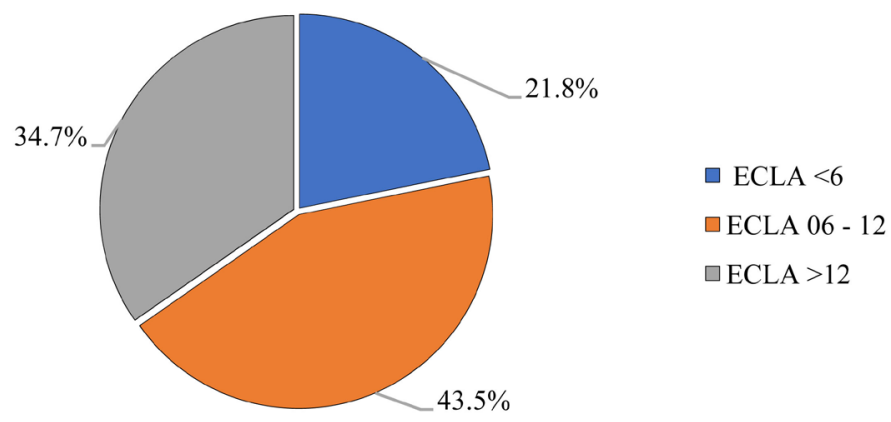

Figure 2. Distribution according to the severity of acne among the 129 patients seen in Departments of Dermatology in CNHU-HKM Cotonou and CHUD-B/A Parakou at January 2017 to December 2018.

\section{Discussion}

The average age of the 129 participants was 24.6 years \pm 8.5 years with extremes of 11 years and 56 years. Young people (45.8\%), adults (38.7\%), and women (72.9\%), consulted mostly for acne lesions while pubescent and adolescents represented $12.4 \%$ of consultants and men $27.1 \%$. Our results confirm the observation that the prevalence of adult acne is increasing [4] [5] [6] [14]. On the other hand, this increase in prevalence is more likely for adult and young women [2] [3] [4] [5] [7]. It is often the continuation of adolescent acne or late-onset acne since the median age of onset was 17.9 years \pm 7.6 years [1] [4] [8].

The low proportion of adolescents may be explained by the fact that acne is a condition neglected by parents who consider it a normal physiological phenomenon in adolescents [3] [4] [7]. So our sample couldn't represent the whole population.

The majority of patients had predominantly inflammatory acne $(51.9 \%)$. Although the physiopathology of acne is the same regardless of cutaneous phenotype, it has been reported by several authors that subjects with pigmented skin more often develop inflammatory acne [7] [8] [10]. Histopathological images demonstrate an exaggerated inflammatory response even in non-inflammatory lesions [2] [8] [9]. This would explain the high frequency of post-inflammatory hyperpigmentations on pigmented skin [3] [7] [11].

For other authors, delayed consultation would be the basis of the inflammatory stage observed during the consultation [8] [12]. This delay was also noted during our study because the median consultation time was 5.1 years \pm 7.1 years. In this case, this inflammatory predominance is the consequence of self-medication based on bad cosmetics or drugs [3] [4] [12] [15]. The latter would be source of aggravation of primary lesions evolving to hyperpigmented scars (70.5\%) after excoriation $(48.1 \%)$ of the primary lesions. In order to reduce or hide these hyperpigmented scars, patients frequently use depigmenting $(32.5 \%)$ or comedogenic (9.3\%) cosmetic that only aggravated acne [4] [5] [6] [7] [8]. It creates a vicious circle that is difficult to break [7] [8] [9].

Previous studies have shown that acne predominates on the cheeks and forehead on pigmented skin whereas on white skin elective topography was the re- 
gion of the beard [1] [4] [8] [12]. Our study confirms the elective involvement of the forehead (92.2\%) and the cheeks (86.8\%) irrespective of the physiological age of the patient. This phenomenon in linked to the use of comedogenic cosmetics for fair care and facial care [1] [10] [12].

It has been reported by some authors that people with pigmented skin often develop severe acne [3] [7] [8]. The majority of our patient had moderate (43.5\%) and severe (34.7\%) acne, compared with South Africa and French, where mild to moderate acne predominated [2] [16]. There is therefore an interracial but also intra-racial difference in the clinical presentation of acne.

In our series, women were more likely to have moderate acne $(52.1 \%)$ while it was severe in almost $2 / 3$ of men. Despite the severity of acne, nodulo-cystic lesions were observed in only $15.5 \%$ and snow-peak scars in $10.9 \%$ of them. This confirms the observation that pigmented skin exhibited fewer nodulo-cystic lesions and snow-peak scars than Caucasians [2] [7] [10].

In addition, our results reveal that men are more likely to develop severe acne. Increased hyperseborrhea and increased bacterial colonization in men are predictive of this severity [10] [11]. Studies on large cohort will confirm this observation and look for other risk factors.

In our study, prescription of active cosmetics was more important than that conventional medication. These cosmetics are endowed with several beneficial properties for the treatment of acne. They can be sebum-regulating, anti-inflammatory, keratolytic, depigmenting and sometimes antibacterial without risk of resistance [6] [14] [17] [18]. In addition, they are easier to use, effective and have a fairly good tolerance compare to anti-acne drugs [2] [6] [14] [18]. Despite the high proportion of hyperpigmented scars and greater susceptibility to the hyperpigmenting evolution of acne on pigmented skin, photoprotective agent was very rarely prescribed in dermatology in Benin. The same observation has been made by some authors [10] [13].

However, acne on pigmented skin is rapidly inflammatory and often has a hyperpigmenting evolution. These post-inflammatory hyperpigmentations are unsightly and frequently lead the impaired quality of life [1] [7]. They constitute the most frequent reason of consultation [2] [5] [9]. Studies that can find the most appropriate treatments for pigmented skin acne as envisaged by some authors [10] [11] should improve the quality of life of patents. For this, we recommend, as others authors, studies that will help to find the best suited treatment for acne on pigmented skin.

\section{Conclusion}

Our study notes a prevalence of acne in young and adult woman in hospitals in Parakou and Cotonou. Acne was often cosmeto-induced or cosmeto-aggravated, manifested primarily by inflammatory lesions and post-inflammatory hyperpigmentations that electively sat on the forehead and cheeks. Flares were often moderate in women and severe in men. The treatment of acne in dermatology in Benin was mainly based on the use of active cosmetics associated with conven- 
tional treatment and seemed less focused on hyperpigmentation. Subsequent studies would better evaluate the therapeutic efficacy and look for the best suited treatments for acne on pigmented skin.

\section{Conflicts of Interest}

The authors declare no conflicts of interest regarding the publication of this paper.

\section{References}

[1] Addor, F.A.S. and Schalka, S. (2010) Acne in Adult Women: Epidemiological, Diagnostic and Therapeutic Aspects. Anais Brasileiros de Dermatologia, 85, 789-795. https://doi.org/10.1590/S0365-05962010000600003

[2] Zulu, T.P., Mosam, A., Balakrishna, Y. and Dlova, N.C. (2017) Acne in South African Black Adults: A Retrospective Study in the Private Sector. South African Medical Journal, 107, 1106-1109. https://doi.org/10.7196/SAMJ.2017.v107i12.12419

[3] Saka, B., Akakpo, A.S., Técléssou, J.N., Mouhari-Touré, A., Mahamadou, G., Gnossikè, P., Gnassingbé, W., Abilogoun-Chokki, A., Tawelessi, A., Kombaté, K. and Pitché, P. (2018) Acne in Lomé, Togo: Clinical Aspects and Quality of Life of Patients. BMC Dermatology, 18, 7. https://doi.org/10.1186/s12895-018-0075-z

[4] Kane, A., Oumou Niang, S., Cisse Diagne, A., et al. (2007) Epidemilogic Clinical, and Therapeutic Features of Acne in Dakar Senegal. International Journal of Dermatology, 46, 36-38. https://doi.org/10.1111/j.1365-4632.2007.03462.x

[5] Ncoza, C., Mosam, D.A. and Tsoka-Gwegweni, J. (2018) The Spectrum and Sequelae of Acne in Black South Africans Seen in Tertiary Institutions. Skin Appendage Disorders, 4, 301-303. https://doi.org/10.1159/000488689

[6] Araviiskaia, E., Lopez Estebaranz, J.L. and Pincelli, C. (2019) Dermocosmetics: Beneficial Adjuncts in the Treatment of Acne Vulgaris. Journal of Dermatological Treatment, 1-8. https://doi.org/10.1080/09546634.2019.1628173

[7] Kouotou, E.A., Adegbidi, H., Bene Belembe, R., Sieleunou, I., Nansseu, J.R., Kamga, J.-P., et al. (2016) Acné au Cameroun: Qualité de vie et comorbidités psychiatriques. Annales de Dermatologie et de Vénéréologie, 143, 601-606. https://doi.org/10.1016/j.annder.2016.05.011

[8] Poli, F., Faye, O., Ly, F. and Le Thuaut, A. (2014) Acné de la femme adulte: Etude clinique en France et en Afrique Sub-sahélienne. Annales de Dermatologie et de Vénéréologie, 141, 336-345. https://doi.org/10.1016/j.annder.2014.01.019

[9] Yin, N.C. and McMichael, A.J. (2014) Acne in Patients with Skin of Color: Practical Management. American Journal of Clinical Dermatology, 15, 7-16. https://doi.org/10.1007/s40257-013-0049-1

[10] Davis, E.C. and Callender, V.D. (2010) A Review of Acne in Ethnic Skin Pathogenesis, Clinical Manifestations, and Management Strategies. The Journal of Clinical and Aesthetic Dermatology, 3, 24-38.

[11] Perkins, A.C., Cheng, C.E., Hillebrand, G.G., Miyamoto, K. and Kimball, A.B. (2011) Comparison of the Epidemiology of Acne Vulgaris among Caucasian, Asian, Continental Indian and African American Women. Journal of the European Academy of Dermatology and Venereology, 25, 1054-1060. https://doi.org/10.1111/j.1468-3083.2010.03919.x

[12] Anonymous (2007) Acne Vulgaris in Richly Pigmented Patients. Dermatologic 
Therapy, 20, 122-127. https://doi.org/10.1111/j.1529-8019.2007.00122.x

[13] Poli, F. (2007) Acne on Pigmented Skin. International Journal of Dermatology, 46, 39-41. https://doi.org/10.1111/j.1365-4632.2007.03463.x

[14] Araviiskaia, E. and Dreno, B. (2016) The Role of Topical Dermocosmetics in Acne Vulgaris. Journal of the European Academy of Dermatology and Venereology, 30, 926-935. https://doi.org/10.1111/jdv.13579

[15] Kombaté, K., Mouhari-Toure, A., Saka, B., Akakpo, A.S., Maboudou, A., Pitché, P. and Tchangaï-Walla, K. (2012) Acné et blanchiment de la peau à Lomé (Togo). International Journal of Dermatology, 51, 30-32. https://doi.org/10.1111/j.1365-4632.2012.05560_suppl.x

[16] Goh, C.L., Noppakun, N., Micali, G., Azizan, N.Z., Boonchai, W., Chan, Y., et al. (2016) Meeting the Challenges of Acne Treatment in Asian Patients: A Review of the Role of Dermocosmetics as Adjunctive Therapy. Journal of Cutaneous and Aesthetic Surgery, 9, 85-92. https://doi.org/10.4103/0974-2077.184043

[17] Dréno, B., Alirezai, M., Auffret, N., Beylot, C., Chivot, M., Daniel, F., et al. (2007) Clinical and Psychological Correlation in Acne: Use of the ECLA and CADI Scales. Annales de Dermatologie et de Vénéréologie, 134, 451-455. https://doi.org/10.1016/S0151-9638(07)89212-X

[18] Poli, F., Claudel, J.-P., Auffret, N., Leccia, M.-T. and Dréno, B. (2017) Cosmétiques et médicaments topiques dans l'acné: Où est la frontière? Annales de Dermatologie et de Vénéréologie, 144, 768-775 https://doi.org/10.1016/j.annder.2017.08.011 